\title{
Ligating the Ductus Arteriosus before birth Remodels the Pulmonary Vasculature of the Lamb
}

\author{
LINDA M. WILD, PETER A. NICKERSON, AND FREDERICK C. MORIN III \\ Departments of Pathology [L.M.W., P.A.N.] and Pediatrics [F.C.M.], State University of New York at Buffalo, \\ Buffalo, New York 14214
}

\begin{abstract}
The clinical syndrome of persistent pulmonary hypertension of the newborn includes a developmentally abnormal pulmonary microvasculature which contains excessive amounts of muscle and which cannot adapt to air breathing in the perinatal period. Surgical ligation of the ductus arteriosus of the fetal lamb has produced a physiologic model of pulmonary hypertension of the newborn. The aim of the present investigation is to determine whether surgical ligation of the ductus arteriosus in fetal sheep produces anatomic changes in the pulmonary blood vessels. The pulmonary vasculature of seven neonatal lambs that underwent surgical ligation of the ductus arteriosus from 6 to $17 \mathrm{~d}$ before birth was compared to that of five control lambs with a patent ductus arteriosus without fetal surgery and three control lambs with a patent ductus arteriosus that underwent sham surgery. Quantitative microscopic analysis of the barium gelatin-filled peripheral pulmonary vascular bed revealed an increase in the proportion of partially and fully muscularized pulmonary arteries at the level of the terminal bronchiole and within the acinus $(p<0.0001)$. This finding demonstrates that medial muscle develops in areas of the distal pulmonary vascular bed where it is normally absent. Periadventitial fibrosis surrounding intraacinar pulmonary arteries was also present. No change in the number of small intraacinar arteries was detected. This structural remodeling of the peripheral pulmonary vascular bed was initiated in utero by ductus arteriosus occlusion. Prenatal closure of the ductus arteriosus for 6 to $17 \mathrm{~d}$ in fetal lambs produces anatomic changes in small pulmonary arteries of the newborn lamb. These anatomic changes are similar to pathologic alterations reported in human neonates dying with idiopathic persistent pulmonary hypertension of the newborn. (Pediatr Res 25:251-257, 1989)
\end{abstract}

\section{Abbreviations}

PPHN, persistent pulmonary hypertension of the newborn ED, external diameter

MT, medial thickness

The clinical syndrome of idiopathic PPHN is characterized morphologicaily by the abnormal presence of muscle in the walls of the smallest pulmonary artery branches (1). The etiology of PPHN occurring in the absence of primary cardiac, pulmonary,

Received July 25, 1988; accepted October 27, 1988

Correspondence Linda M. Wild, M.D., Department of Pathology, 204 Farber Hall, SUNY at Buffalo, Buffalo, NY 14214.

Supported in part by funds from NIH 1 Pol HL34323-02 or hematologic disorders is unknown. Prenatal ligation of the ductus arteriosus 6 to $17 \mathrm{~d}$ before birth in fetal lambs produces physiologic characteristics similar to the human syndrome (2). We studied the peripheral pulmonary vasculature in these lambs to identify histologic changes in pulmonary arteries and to determine whether these changes represented an experimental model which reproduced the human disease.

\section{MATERIALS AND METHODS}

Animals studied and surgical preparation. The study included 15 neonatal lambs: five control lambs with patent ductus arteriosus during fetal development and without fetal surgery, three control lambs with a patent ductus arteriosus and sham surgery, and seven lambs that had ligation of the ductus arteriosus from 6 to $17 \mathrm{~d}$ before birth. The surgical preparation has been described in detail (2) and will be only summarized here. Seven pregnant ewes at 123-134 d of gestation were operated upon under halothane anesthesia. The fetus was exposed through a hysterotomy, a thoracotomy performed, and the ductus arteriosus was ligated. The fetus was returned to the uterus, and the ewe and fetus recovered from surgery. Between 138 and $142 \mathrm{~d}$ of gestation, these fetuses were delivered, producing newborn lambs that had been exposed to 6-17 d of prenatal ductus arteriosus ligation. They lived and breathed air for several $h$ after birth while physiologic measurements were made. Similarly, three control fetuses were operated upon under halothane anesthesia $14 \mathrm{~d}$ before birth. They underwent maternal hysterotomy followed by fetal thoracotomy, incision of the pericardium and visualization, but not ligation of the ductus arteriosus. At $140 \mathrm{~d}$ of gestation, these fetuses were delivered; they lived for 3 to $5 \mathrm{~h}$ while undergoing physiologic measurements. Five control fetuses that did not have surgery were delivered at 134-142 d of gestation. After ventilation for 3-5 h, all lambs were sacrificed with phenobarbital injection.

Preparation of tissue. The trachea, lungs, and heart were immediately removed en bloc from the chest cavity through a midline sternotomy and frozen (3). They were later thawed by immersion in a water bath at $40^{\circ} \mathrm{C}$. The right ventricle was incised, and a wide bore catheter was inserted through the right ventricle into the main pulmonary artery, where it was secured with a ligature. The left atrium was opened to allow outflow. The pulmonary arteries were injected with a warm barium gelatin suspension (400 ml micropaque powder, Nicholas Picker Co., Stoughton, MA; 50 g gelatin, Bloom 8-G, Fisher Scientific Co., Fairlawn, NJ; $500 \mathrm{ml}$ distilled water, and a few crystals of phenol) at $75 \mathrm{~cm}$ water pressure and $60^{\circ} \mathrm{C}$ for $2 \mathrm{~min}$ using the technique of Reid adapted from the method of Short (4-6). This injection technique fills all pulmonary artery branches greater than approximately $10 \mu \mathrm{m}$ in diameter, but does not easily pass through the capillary bed. It thus differentiates intraalveolar precapillary 
arteries from postcapillary venules. It provides uniform distention of all pulmonary arteries, and it also permits landmarking of pulmonary arteries in relation to their accompanying airway. The trachea was cannulated, and the lungs were infused with $10 \%$ neutral buffered formalin at $25 \mathrm{~cm} \mathrm{H}_{2} \mathrm{O}$ pressure until all lung lobes were firmly distended and the lung margins were well defined. The trachea was then ligated, and the fully distended lungs were immersed in fixative for at least $24 \mathrm{~h}$. Pulmonary arteriograms were prepared from each lamb using fine grain film and $55 \mathrm{keV}, 10 \mathrm{ma}$ and $0.16 \mathrm{~s}$.

Lungs were then serially sectioned at 2- to $3-\mathrm{mm}$ intervals, and the slices were arranged in a single layer under a plastic transparency imprinted with equidistant numbered points. Five blocks of parenchymal tissue were selected from each animal using a random number table, thus providing an A-weighted random tissue sample (7). Tissue blocks were processed through graded alcohols, embedded in paraffin, and sectioned at $4 \mu \mathrm{m}$. Tissue sections were stained with hematoxylin and eosin and Miller's elastic Van Gieson method to demonstrate elastic tissue and smooth muscle.

Analysis of tissue sections. In each animal, at least 50 arteries were analyzed at $1000 \times$, including a minimum of 10 arteries in each of the five categories used in this study. Each artery was identified or landmarked by the airway it accompanied. In this study, preacinar pulmonary arteries were defined as those vessels located adjacent to terminal bronchioles or bronchioles. Intraacinar pulmonary arteries were those vessels located next to respiratory bronchioles and alveolar ducts or small barium gelatin-filled vessels within the alveolar wall.

With a filar micrometer (American Optical, Buffalo, NY), the ED of each artery was measured as the shortest distance between the outer elastic lamina in any tangential section, and the MT of muscular and partially muscular arteries was measured as the distance between internal and external elastic lamina in the same plane. For each fully muscular pulmonary artery, medial thickness was related to external diameter as a percentage of MT according to the formula $\% \mathrm{MT}=2 \mathrm{MT} / \mathrm{ED} \times 100$. For each partially muscular pulmonary artery, the formula $\% \mathrm{MT}=\mathrm{MT} /$ ED $\times 100$ was used $(8)$.

For each animal, the density of barium-filled arteries was assessed by counting the number of filled arteries and alveoli in 10 consecutive high-power microscopic fields. The ratio of alveoli to filled arteries was determined.

From the arteriogram, the lumen diameter of the axial artery of each lung was measured at the hilum and at $10 \%$ intervals from the hilum to the level where it appeared to end, a few millimeters from the pleural surface.

For analysis, arteries were categorized according to their position in the respiratory tree. Preacinar arteries were divided into those accompanying bronchioles and terminal bronchioles, and intraacinar arteries were grouped into those accompanying respiratory bronchioles, alveolar ducts, and those within the alveolar wall. All microscopic sections were examined without knowledge of the experimental group to which the lamb belonged. External diameter, medial thickness, and percentage of MT of arteries from lambs with patent and ligated ductus arteriosus were compared at each preacinar and intraacinar level using the $t$ test. The mean \pm SEM were obtained for each animal and each feature studied. The distribution of vessels by wall structure was examined by chi-square analysis except at the level of the alveolar duct and the alveolar wall where Fisher's exact test was used because some expected frequencies were 0 . When three groups were compared, the Bonferroni correction was used, and a 0.016 significance level was selected. Linear regression analysis was used to determine the relationship between peripheral extension of arterial muscle and the duration of prenatal ductus arteriosus ligation.

\section{RESULTS}

No significant difference was found between the control groups of lambs with and without sham surgery for any macroscopic or microscopic characteristic; therefore, in the text, all untreated lambs are collectively referred to as control lambs or as lambs with a patent ductus arteriosus unless otherwise specified.

Wt and gestational age. The fetal lambs with a patent ductus arteriosus weighed between 2.45 and $4.2 \mathrm{~kg}$ at birth. Fetal lambs with prenatal ligation of the ductus arteriosus showed a similar distribution of wt, ranging between 2.55 and $4.30 \mathrm{~kg}$ at birth. Lung wt were similar in the lambs with ligated and patent ductus arteriosus (ligated: $22.9 \pm 2.7 \mathrm{~g} / \mathrm{kg}$ body wt, control: $23.8 \pm 1.8$ $\mathrm{g} / \mathrm{kg}$ body wt). Control lambs were delivered at $134-142 \mathrm{~d}$ of gestation, and lambs with surgically ligated ductus were delivered at $138-142 \mathrm{~d}$ of gestation.

Macroscopic appearance of lungs and pulmonary arteriograms. Lungs of all lambs showed the normal number and configuration of lobes. Vascular filling was uniform in the pulmonary arterio-
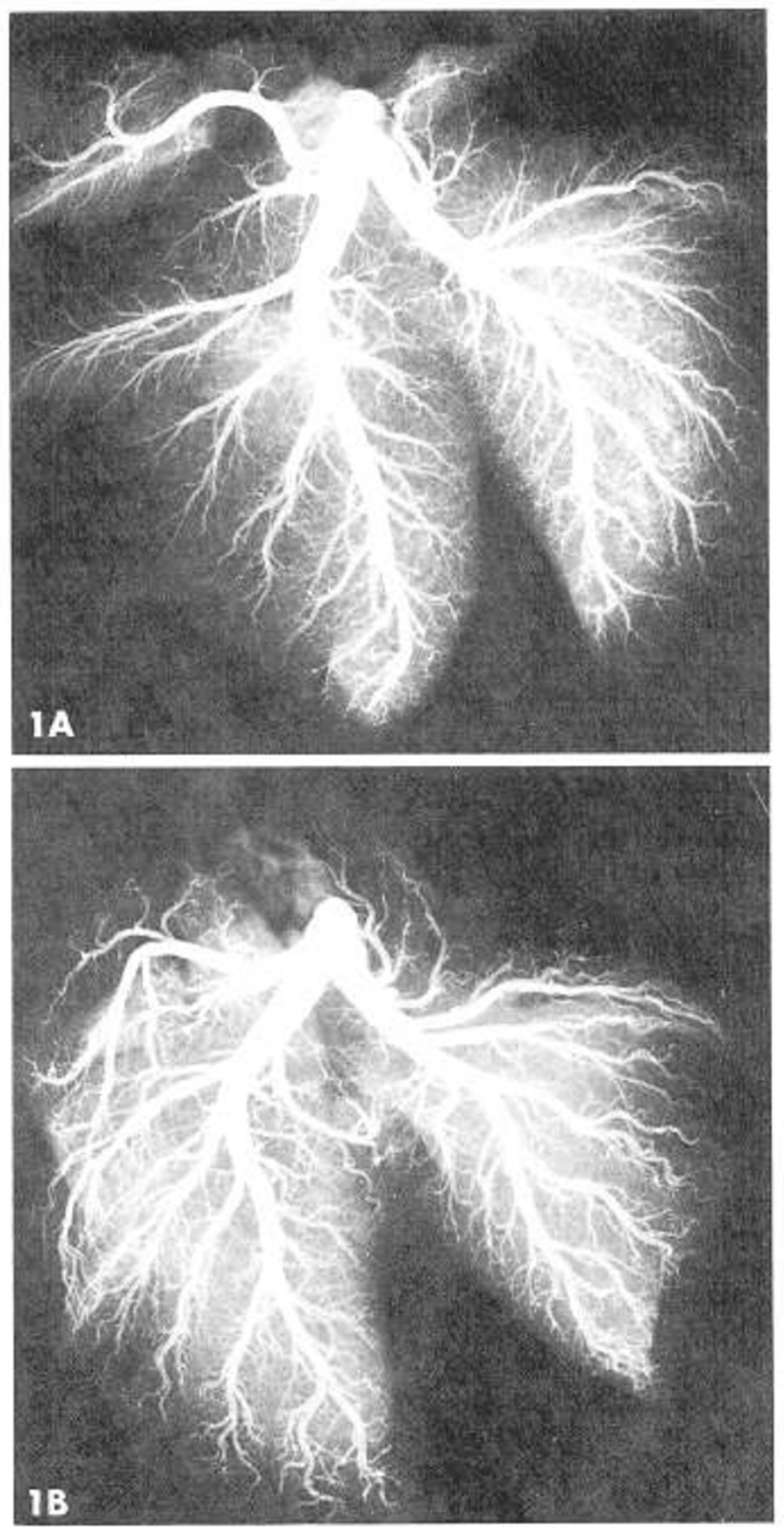

Fig. 1. Newborn lamb pulmonary arteriograms: $A$, control; $B$, prenatal ductus arteriosus ligation for $8 \mathrm{~d}$. No difference in arterial branching pattern, axial artery diameter, or background haze is identified (original magnification, $\times 1.5$ ) 
grams of lambs with both patent and ligated ductus arteriosus. No difference was found between groups in the branching pattern of the pulmonary arterial tree, diffuse background haze (representing filling of small intraacinar arteries), and the length and lumen diameter of large axial arteries (Fig. 1).

Histologic features of pulmonary arteries. Microscopic examination of the lungs revealed two abnormal features of the pulmonary arterial tree. The most prominent of these changes was the presence of muscle in smaller and more peripherally located arteries (Tables 1 and 2). The most striking shift in the distribution of muscularized arteries occurred within the acinus (Table 2 ); however, changes were also found in pulmonary arteries at the level of the terminal bronchiole (Table 1). In arteries associated with respiratory bronchioles, fully and partially muscularized vessels accounted for $90.5 \%$ of the total in ligated lambs compared with $27 \%$ in sham-operated controls. In alveolar duct arteries, $29 \%$ were fully or partially muscularized in ligated newborns versus $3 \%$ in sham-operated controls; alveolar wall arteries which are normally all nonmuscular showed the development of partially or fully muscularized walls in $8.5 \%$. Pulmonary arteries associated with terminal bronchioles showed a less striking but still significant change in the degree of muscularization with fully and partially muscular vessels accounting for $90 \%$ of the total in sham-operated control lambs versus $100 \%$ in ligated lambs. No difference in muscle distribution was found in arteries accompanying bronchioles that were all fully muscularized in both control and ligated groups. Linear regression analysis showed a significant correlation between the increasing proportion of fully muscularized pulmonary arteries at the level of the respiratory bronchiole and the duration of ductus arteriosus ligation $(r=0.81, p<0.001)$ and between the decreasing proportion of nonmuscularized pulmonary arteries at the level of the respiratory bronchiole and alveolar duct and the duration of ductus arteriosus ligation (respiratory bronchiole: $r=0.77, p$ $<0.003$, alveolar duct: $r=0.73, p<0.01$ ).

The second morphologic finding of interest was the presence of periadventitial fibroconnective tissue (Fig. 2). This feature was identified qualitatively in muscularized intraacinar and terminal bronchiolar pulmonary arteries, and the proliferation was most marked in lungs of newborn lambs with more than 1 wk of prenatal ductal occlusion. No difference in the ratio of alveoli to intraacinar arteries was found between groups. No pulmonary thrombemboli were found.

At most pre- and intraacinar locations, the ED of arteries did not change in size when compared to either sham- or nonoperated control lambs; however, at two locations, ED did change (Tables 3 and 4). In the preacinar group, the ED of pulmonary arteries accompanying terminal bronchioles were significantly smaller than the same arteries in sham-operated lambs. In the intraacinar blood vessels, ED of fully muscular pulmonary arteries accompanying respiratory bronchioles increased compared to nonoperated controls, and ED of partially muscular pulmonary arteries at this level decreased compared to sham-operated controls. Vessel size thus changed in only two places, and in one of these locations external diameters both increased and decreased depending on whether fully or partially muscularized vessels were analyzed. MT of muscle increased in treated lambs in only partially muscular arteries accompanying respiratory bronchioles (Table 4).

\section{DISCUSSION}

Newborn lambs with ductus arteriosus ligation before birth had pulmonary pathologic alterations which show similarities to those described in human neonates with the fatal clinical syndrome of PPHN (1). Quantitative microscopic examination of the lungs of newborn lambs with prenatal ligation of the ductus

Table 1. Number and percentage of fully muscular, partially muscular and nonmuscular pulmonary arteries associated with preacinar airways in newborn lambs with patent and ligated ductus arteriosus

\begin{tabular}{|c|c|c|c|c|c|c|}
\hline \multicolumn{4}{|c|}{ Bronchioles } & \multicolumn{3}{|c|}{ Terminal bronchioles } \\
\hline Status of ductus & $\begin{array}{c}\text { Degree of } \\
\text { muscularization }\end{array}$ & $\begin{array}{l}\text { No. of } \\
\text { arteries }\end{array}$ & $\begin{array}{c}\% \\
\text { distribution }\end{array}$ & $\begin{array}{c}\text { Degree of } \\
\text { muscularization }\end{array}$ & $\begin{array}{l}\text { No. of } \\
\text { arteries }\end{array}$ & $\begin{array}{c}\% \\
\text { distribution }\end{array}$ \\
\hline \multirow[t]{3}{*}{ Sham-operated controls $(n=3)$} & Fully & 30 & 100 & Fully & 23 & 77 \\
\hline & Partially & 0 & & Partially & 4 & 13 \\
\hline & Absent & 0 & & Absent & 3 & 10 \\
\hline \multirow[t]{3}{*}{ Nonoperated controls $(n=5)$} & Fully & 51 & 100 & Fully & 41 & 80 \\
\hline & Partially & 0 & & Partially & 6 & 12 \\
\hline & Absent & 0 & & Absent & 4 & 8 \\
\hline \multirow[t]{3}{*}{ Ligated $(n=7)$} & Fully & 80 & 100 & Fully & 99 & $97^{*}$ \\
\hline & Partially & 0 & & Partially & 3 & $3^{*}$ \\
\hline & Absent & 0 & & Absent & 0 & \\
\hline
\end{tabular}

* Distribution of arteries significantly different from sham- and nonoperated control groups, $p<0.0001$.

Table 2. Number and percentage of fully muscular, partially muscular and nonmuscular pulmonary arteries associated with intraacinar airways in newborn lambs with patent and ligated ductus arteriosus

\begin{tabular}{|c|c|c|c|c|c|c|c|c|c|}
\hline \multicolumn{4}{|c|}{ Respiratory bronchiole } & \multicolumn{3}{|c|}{ Alveolar duct } & \multicolumn{3}{|c|}{ Alveolar wall } \\
\hline $\begin{array}{c}\text { Status of ductus ar- } \\
\text { teriosus }\end{array}$ & $\begin{array}{c}\text { Degree of mus- } \\
\text { cularization }\end{array}$ & $\begin{array}{l}\text { No. of } \\
\text { arteries }\end{array}$ & $\begin{array}{l}\text { \% distribu- } \\
\text { tion }\end{array}$ & $\begin{array}{c}\text { Degree of mus- } \\
\text { cularization }\end{array}$ & $\begin{array}{l}\text { No. of } \\
\text { arteries }\end{array}$ & $\begin{array}{l}\text { \% distribu- } \\
\text { tion }\end{array}$ & $\begin{array}{c}\text { Degree of mus- } \\
\text { cularization }\end{array}$ & $\begin{array}{l}\text { No. of } \\
\text { arteries }\end{array}$ & $\begin{array}{l}\% \text { distribu- } \\
\text { tion }\end{array}$ \\
\hline \multirow{3}{*}{$\begin{array}{l}\text { Sham-operated } \\
\quad \text { controls }(n=3)\end{array}$} & Fully & 0 & & Fully & 0 & & Fully & 0 & \\
\hline & Partially & 8 & 27 & Partially & 1 & 3 & Partially & 0 & \\
\hline & Absent & 22 & 73 & Absent & 29 & 97 & Absent & 30 & 100 \\
\hline \multirow{3}{*}{$\begin{array}{l}\text { Nonoperated con- } \\
\quad \text { trols }(n=5)\end{array}$} & Fully & 4 & 7.5 & Fully & 0 & & Fully & 0 & \\
\hline & Partially & 16 & 30.0 & Partially & 2 & 4 & Partially & 0 & \\
\hline & Absent & 33 & 62.5 & Absent & 49 & 96 & Absent & 51 & 100 \\
\hline \multirow[t]{3}{*}{ Ligated $(n=7)$} & Fully & 53 & $55.0^{*}$ & Fully & 11 & $12^{*}$ & Fully & 1 & $1.0^{*}$ \\
\hline & Partially & 34 & $35.5^{*}$ & Partially & 15 & $17^{*}$ & Partially & 6 & $7.5^{*}$ \\
\hline & Absent & 9 & $9.5^{*}$ & Absent & 63 & $71 *$ & Absent & 74 & $91.5^{*}$ \\
\hline
\end{tabular}

* Distribution of arteries significantly different from sham- and nonoperated control groups, $p<0.0001$. 

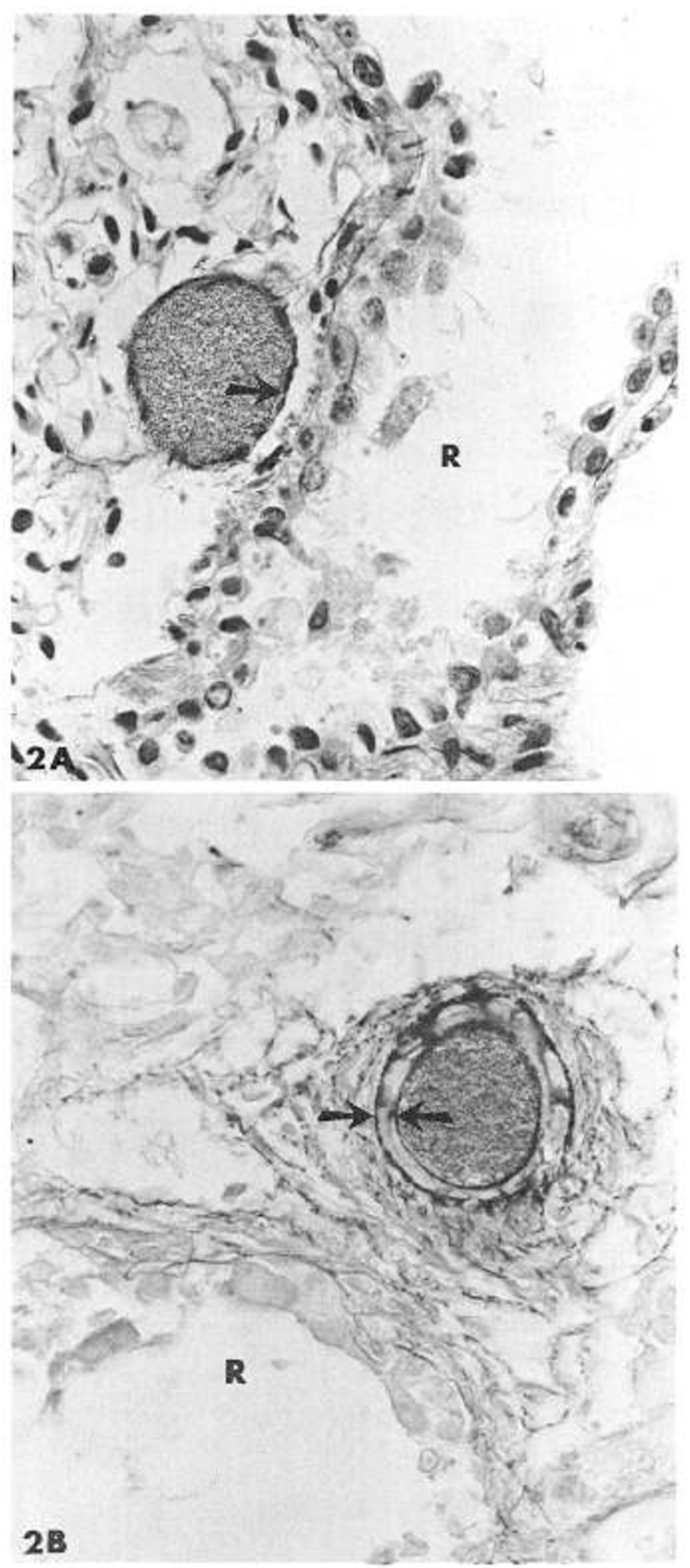

Fig. 2. Photomicrograph of branches of the pulmonary artery associated with respiratory bronchioles. The lumen of each artery is filled with densely staining barium-gelatin particles. $A$, a pulmonary artery (25 $\mu \mathrm{m} \mathrm{ED)} \mathrm{with} \mathrm{a} \mathrm{single} \mathrm{elastic} \mathrm{lamina} \mathrm{(arrow)} \mathrm{and} \mathrm{nonmuscular} \mathrm{arterial}$ wall from a control lamb. $B$, a pulmonary artery $(28.5 \mu \mathrm{m} \mathrm{ED})$ with a double elastic lamina (arrows), muscularized arterial wall, and adventitial fibrosis from a lamb in which the ductus arteriosus was ligated for $15 \mathrm{~d}$ in utero. Respiratory bronchiole $(R)$. Paraffin embedded section $(4 \mu \mathrm{m})$ stained with Miller's elastic stain $(\times 512)$.

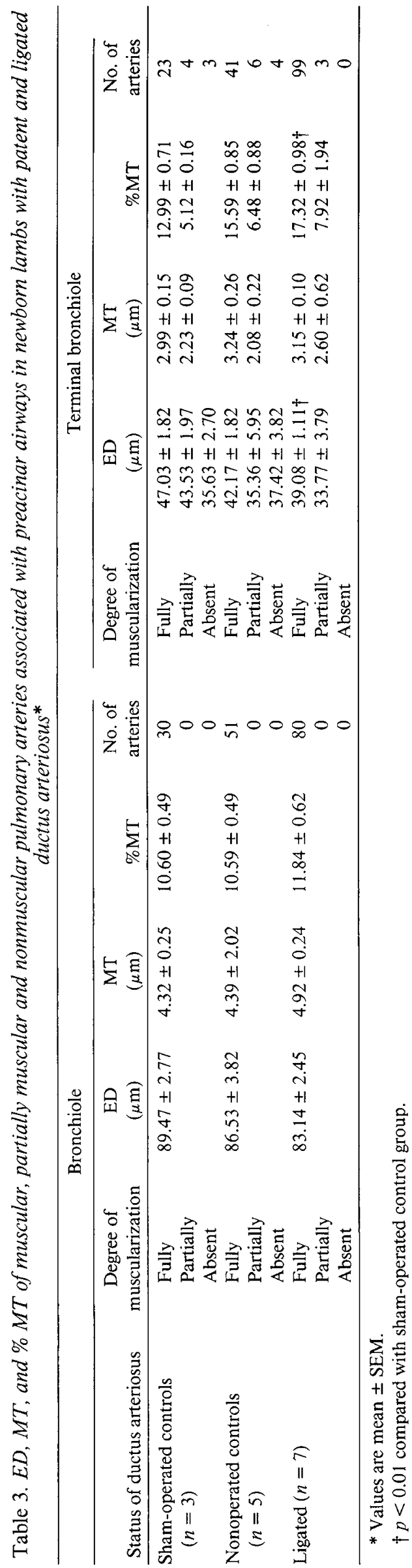




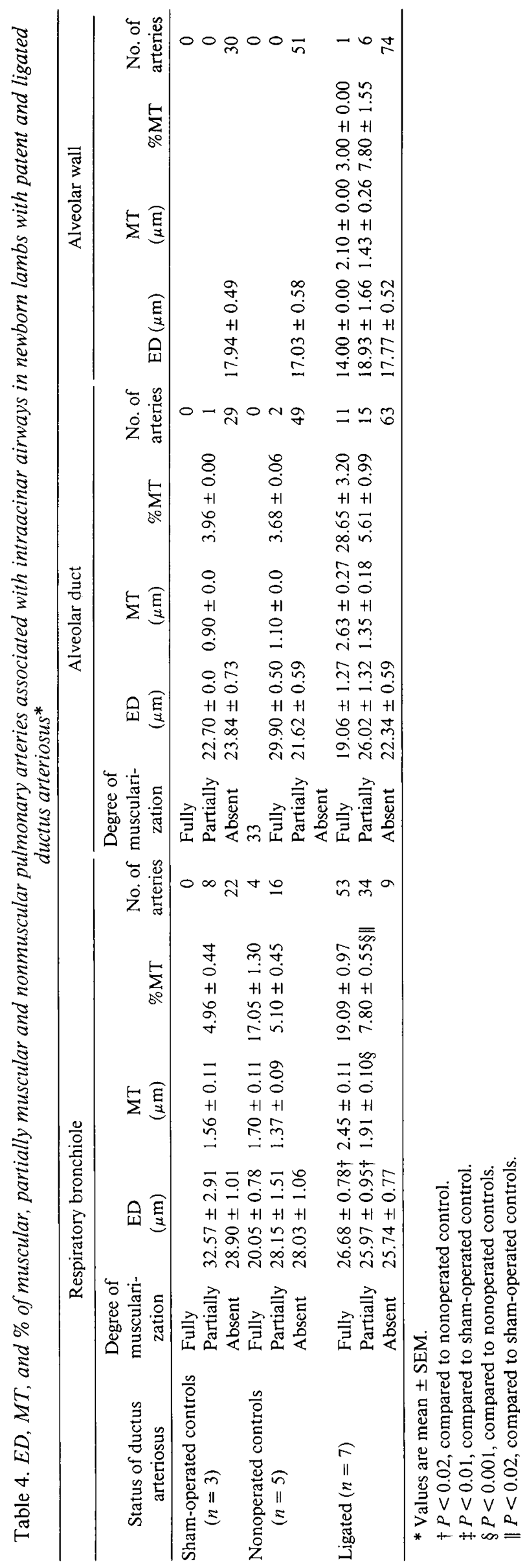

arteriosus revealed the development of smooth muscle in the media of intraacinar pulmonary arteries which are normally nonmuscular. Control lambs with a patent ductus arteriosus during fetal development had either fully or partially muscularized arterial walls in almost all preacinar pulmonary arteries (arteries larger than $35 \mu \mathrm{m}$ ). Intraacinar arteries, however, contained very little medial muscle. This abrupt decline in the proportion of muscularized arteries was found proximally in the acinus where approximately two-thirds of pulmonary arteries accompanying respiratory bronchioles were nonmuscular. Virtually all pulmonary arteries found distally within the acinus were nonmuscular. A previous anatomic study of the pulmonary vasculature of the fetal lamb (9) has shown a constant medial width to ED ratio of pulmonary arteries of various sizes over the gestational period. However, that study did not landmark all arteries by their position in relation to bronchioles and did not report population counts of muscularized arteries at each anatomic level. The histologic finding of muscularization of almost all preacinar pulmonary arteries with an abrupt transition to nonmuscularized vessels within the acinus establishes the structure of the pulmonary microvasculature of the newborn lamb. It also shows that the anatomic distribution of arterial muscle in the distal lung of the normal newborn lamb is quite similar to the arrangement which exists in normal human newborns (1). In contrast, newborn lambs with prenatal ligation of the ductus arteriosus showed a significantly increased proportion of muscularized pulmonary arteries at all intraacinar locations. This muscle was present in anatomic locations where it is not normally seen, and it represents the appearance of newly formed muscle. Meyerick and Reid (10) have shown that the development of this new muscle results from stimulation and metaplasia of precursor cells which are normally found in the subendothelial location in nonmuscular pulmonary arteries.

An increase in the proportion of muscularized pulmonary arteries within the acinus has been identified in both humans and animals with pulmonary hypertension due to various causes including hypoxia (11), congenital heart disease (12), and PPHN (1). In the small number of human infants with lethal PPHN whose lungs have been studied quantitatively, all intraacinar arteries have been muscularized. Treated animals in the present study, although showing a significant distal extension of muscle within the acinus, do not show this change to as severe a degree as is found in children who die from PPHN. As the change in the proportion of muscularized intraacinar pulmonary arteries correlated with the duration of ductus arteriosus ligation, this structural change might become more severe if animals were exposed to a longer period of ductal ligation. Given modern intensive care, the lambs in this study may have been survivors, and their pulmonary vascular changes could reflect an earlier or less severe form of the clinical syndrome which in humans would not be available for pathologic study or histologic comparison.

Medial muscular thickening was not consistently identified in lambs with prenatal ductal ligation. Rabinovitch et al. (12) have previously described the independent development of abnormal extension of muscle without accompanying medial thickening of intraacinar arteries in cases of congenital heart disease. In those cases, they suggested that muscle extension without medial thickening represented mild disease and that medial thickening developed only after muscularization of all alveolar wall arteries. In the present study, the absence of consistent medial muscle thickening may also indicate an early stage of disease.

Periadventitial fibroblastic proliferation was identified qualitatively surrounding fully muscularized terminal bronchiolar and intraacinar pulmonary arteries. The significance of adventitial fibrosis is not entirely clear, but it has been previously noted in human neonates with lethal PPHN (1), and it may cause decreased vascular compliance and limit dilation of intraacinar resistance vessels. Stenmark et al. (13) have identified and quantitated adventitial thickening caused by fibroblast hyperplasia and increased production of collagen and elastin in pulmonary 
arteries accompanying bronchioles of $134-$ to $277-\mu \mathrm{m}$ diameter in newborn calves with pulmonary hypertension caused by 2 wk of 4300-m simulated altitude. Meyrick and Reid (14) have shown that adventitial thickening caused by both an increase in the number of fibroblasts and in the number of collagen fibers occurs in the hilar pulmonary arteries of rats with hypoxic pulmonary hypertension. They have also shown the rapid development of increased mitotic activity in adventitial fibroblasts of both the hilar and intraacinar pulmonary arteries of rats with hypoxiainduced pulmonary hypertension (15). In that study, increased mitotic activity of adventitial fibroblasts occurred within $1 \mathrm{~d}$ of exposure to hypoxia and preceeded ${ }^{3} \mathrm{H}$-thymidine labeling of medial muscle cells, suggesting that vascular adventitial fibrosis is an earlier response than medial thickening in some types of pulmonary hypertension.

Aside from the development of medial muscle more distally than normal in the acinus and the presence of adventitial fibrosis of small pulmonary arteries, no other abnormality of lung development was detected. The preacinar arterial branching pattern and lumen diameter seen on the arteriogram, microscopic appearance of airways and alveoli, and the alveolar to arterial ratio were unchanged. The anatomic findings of distal appearance of medial muscle and adventitial fibrosis represent remodeling of the pulmonary microvasculature caused by occlusion of the ductus arteriosus during the late intrauterine period. The mechanism by which prenatal ductal occlusion alters the anatomy of small pulmonary arteries remains speculative. Morin and Egan (16) have shown that mechanical closure of the ductus arteriosus immediately increases pulmonary blood flow in the fetal lamb. Although additional fetal measurements of pulmonary blood flow and pulmonary artery pressure during the period of ductal occlusion are needed, it is suspected that these hemodynamic alterations are the stimulus for the anatomic lesions.

A large body of previous work (17-33) and clinical observation $(19,20)$ has associated prenatal occlusion of the ductus arteriosus and development of PPHN. Administration of indomethacin or other prostaglandin synthetase inhibitors to pregnant animals causes ductal constriction and elevation of pulmonary artery pressure in the fetus $(17,18)$. Indomethacin has been implicated in causing intrauterine ductal occlusion and PPHN in human neonates (19). Levin et al. (20), using a unique method of quantitative analysis of the injected pulmonary vasculature, showed increased medial wall thickness of fifth generation pulmonary arteries in two human neonates who died of PPHN after maternal ingestion of prostaglandin synthetase inhibitors (indomethacin, acetylsalicylic acid). However, vessels were not landmarked by the accompanying airway in that study, and it is not certain that muscularized vessels of the same level were being compared. Indomethacin given to pregnant ewes late in gestation caused elevation of pulmonary artery pressure and increased medial thickness of injected fifth generation arteries in the fetus (21). However, in that study, indomethacin also induced a significant decrease in the ED of pulmonary vessels, thus vasoconstriction may have accounted for the change in medial width to ED ratio. Administration of indomethacin to guinea pigs during fetal development did not produce pulmonary artery hypertension or the characteristic vascular changes of PPHN (22). A previous study without injection of the pulmonary vasculature or quantitative analysis found that fetal sheep exposed to 1-2 wk of surgical ligation of the ductus arteriosus developed right ventricular hypertrophy and adventitial fibrosis of small pulmonary arteries (23). Mechanical occlusion of the ductus arteriosus permits evaluation of the hemodynamic effect of ductal closure, without the presence of other pulmonary and systemic changes induced by prostaglandin synthetase inhibition.

The current study demonstrates that prenatal ductal ligation for 6-17 $d$ in fetal sheep causes remodeling of the pulmonary microvasculature with the development of new muscle distally within the ainus and adventitial fibrosis of small pulmonary arteries. These changes, although not as severe as those found in the lethal clinical syndrome of PPHN, are similar to those of PPHN, and they may correspond to an earlier stage of the human syndrome. Future studies to correlate prenatal measurements of pulmonary arterial pressure, blood flow, and resistance with pulmonary microvascular anatomy during the period of fetal ductal ligation would be of interest in defining more precisely the pathogenesis of this abnormally structured pulmonary circulation.

Acknowledgments. The authors are grateful to Daniel Swartz, Sandra Thamer, Elizabeth Lawson, and Robert Linsmair for skilled technical assistance. Brenda Sauka, Rosina Martinec, and Dolores Trippe assisted with typing of the manuscript.

\section{REFERENCES}

1. Murphy JD, Rabinovitch M, Goldstein JD, Reid LM 1981 The structural basis of persistent pulmonary hypertension. J Pediatr 98:962-967

2. Morin, FC 1989 Ligating the ductus arteriosus before birth causes persistent pulmonary hypertension of the newborn lamb. Pediatr Res 25:245-250

3. Fried R, Reid LM 1984 Early recovery from hypoxic pulmonary hypertension: a structural and functional study. J Appl Physiol 57:1247-1253

4. Reid LM 1979 The pulmonary circulation: remodeling in growth and disease. Am Rev Respir Dis 119:531-546

5. Short DS 1959 The application of arteriography to the pathological study of pulmonary hypertension. In: Adams WR, Veith I (ed) Pulmonary Hypertension. Grune and Stratton, New York, pp 232-254

6. Short DS 1956 Post-mortem pulmonary arteriography with special reference to the study of pulmonary hypertension. J Facul Radio 8:118-124

7. Weibel ER 1979 Practical Methods for Biological Morphometry, Vol 1. Academic Press, London, pp 63-100

8. Jones R, Zapol WM, Reid L 1985 Oxygen toxicity and restructuring of pulmonary arteries: a morphometric study. Am J Pathol 121:212-223

9. Levin DL, Rudolph AM, Heymann MA, Phibbs RH 1976 Morphological development of the pulmonary vascular bed in fetal lambs. Circulation 53:144-151

10. Meyrick B, Reid LM 1978 The effect of continued hypoxia on rat pulmonary arterial circulation. Lab Invest 38:188-200

11. Rabinovitch M, Gamble W, Nadas AS, Miettinen OS, Reid L 1979 Rat pulmonary circulation after chronic hypoxia: hemodynamic and structural features. Am J Physiol 236:H818-H827

12. Rabinovitch M, Haworth SG, Casteneda AR, Nadas AS, Reid LM 1978 Lung biopsy in congenital heart disease. Circulation 58:1107-1122

13. Stenmark KS, Fasules J, Hyde DM, Voelkel NF, Henson J, Tucker A, Wilson H, Reeves JT 1987 Severe pulmonary hypertension and arterial adventitial changes in newborn calves at $4300 \mathrm{~m}$. J Appl Physiol 62:821-830

14. Meyrick B, Reid LM 1980 Hypoxia-induced structural changes in the media and adventitia of the rat hilar pulmonary artery and their regression. Am J Pathol 100:151-178

15. Meyrick B, Reid LM 1979 Hypoxia and incorporation of ${ }^{3} \mathrm{H}$-thymidine by cells of the rat pulmonary arteries and alveolar wall. Am J Pathol 96:51-70

16. Morin FC, Egan EA 1988 The effect of closing the ductus arteriosus on the pulmonary circulation of the fetal lamb. J Dev Physiol (in press)

17. Heyman MA, Rudolph AM 1976 Effects of acetylsalicylic acid on the ductus arteriosus and circulation of fetal lambs in utero. Circ Res 38:418-422

18. Levin DL, Mills LJ, Parkey M, Garriott J, Campbell W 1979 Constriction of the fetal ductus arteriosus after administration of indomethacin to the pregnant ewe. J Pediatr 94:647-650

19. Manchester D, Margolis HS, Sheldon RE 1976 Possible association between maternal indomethacin therapy and primary pulmonary hypertension of the newborn. Am J Obstet Gynecol 126:467-469

20. Levin DL, Fixler DE, Morriss FC, Tyson J 1978 Morphologic analysis of the pulmonary vascular bed in infants exposed in utero to prostaglandin synthetase inhibitors. J Pediatr 92:478-483

21. Levin DL, Mills LJ, Weinberg AG 1979 Hemodynamic, pulmonary vascular, and myocardial abnormalities secondary to pharmacologic construction of the fetal ductus arteriosus. Circulation 60:360-365

22. Demello DE, Murphy JD, Aronovitz MJ, Davies P, Reid LM 1987 Effects of indomethacin in utero on the pulmonary vasculature of the newborn guinea pig. Pediatr Res 22:693-697

23. Ruiz V, Piasecki GJ, Balogh K, Polansky BJ, Jackson BT 1972 An experimental model for fetal pulmonary hypertension. Am J Surg 123:468-471

24. Geggel RL, Reid LM 1984 The structural basis of PPHN. In: Philips JB (ed) Clinics in Perinatology, Vol. 11/3 Symposium on Neonatal Pulmonary Hypertension. WB Saunders, Philadelphia, pp 525-549

25. Haworth SG, Reid LM 1976 Persistent fetal circulation: newly recognized structural features. J Pediatr 88:614-620

26. Levin DL, Heymann MA, Kitterman JA, Gregory GA, Phibbs RH, Rudolph AM 1976 Persistent pulmonary hypertension of the newborn infant. J Pediatr 89:626-630

27. Levin DL, Hyman AI, Heymann MA, Rudolph AM 1978 Fetal hypertension and the development of increased pulmonary vascular smooth muscle: a possible mechanism for persistent pulmonary hypertension of the newborn 
infant. J Pediatr 92:265-269

28. Geggel RL, Aronovitz MJ, Reid LM 1986 Effects of chronic in vitro hypoxemia on rat neonatal pulmonary arterial structure. J Pediatr 108:756-759

29. Haworth SG, Hislop AA 1981 Adaptation of the pulmonary circulation to extra-uterine life in the pig and its relevance to the human infant. Cardiovasc Res 15:108-119

30. Haworth SG, Hall SM, Chew M, Allen K 1987 Thinning of fetal pulmonary arterial wall and postnatal remodeling: ultrastructural studies on the respi- ratory unit arteries of the pig. Virchows Arch [A] 411:161-171

31. Haworth SG, Hislop AA 1983 Pulmonary vascular development: normal values of peripheral vascular structure. Am J Cardiol 52:578-583

32. Drummond WH, Bissonette JM 1978 Persistent pulmonary hypertension in the neonate: development of an animal model. Am J Obstet Gynecol the neonate:

33. Haller JA, Rodgers BM 1968 Hemodynamic effects of occluding the fetal ductus arteriosus. Am Surg 34:200-204 